\title{
The Impact of Bariatric Surgery on Urinary Incontinence: A Systematic Review and Meta-Analysis
}

\section{Lee, Yung}

2019-12

pÿLee , Y , Yu , J , Tikkinen , K A O , Pdziwiatr , M , Major , P , Aditya , I , Krakowsky , Y, Doumouras , A G , Gmora , S , Anvari , M \& Hong , D 2019 , ' The Impact of Bariatric Surgery on Urinary Incontinence: A Systematic Review and Meta-Analysis ', BJU International , vol. 124 , no. 6 , pp. 917-934 . https://doi.org/10.1111/bju.14829

http://hdl.handle.net/10138/315293

https://doi.org/10.1111/bju.14829

unspecified

acceptedVersion

Downloaded from Helda, University of Helsinki institutional repository.

This is an electronic reprint of the original article.

This reprint may differ from the original in pagination and typographic detail.

Please cite the original version. 
Article Category: Review

MR. YUNG LEE (Orcid ID : 0000-0002-6257-4400)

MR. JAMES YU (Orcid ID : 0000-0002-6482-8152)

Article type : Review

Title: The Impact of Bariatric Surgery on Urinary Incontinence: A Systematic Review and Meta-Analysis

\section{Authors:}

Yung Lee BHSc ${ }^{1,2,3}$, James Yu BHSc ${ }^{2,3}$, Kari A.O. Tikkinen MD PhD ${ }^{4}$, Michał Pędziwiatr MD $\mathrm{PhD}^{5,6}$, Piotr Major MD $\mathrm{PhD}^{5,6}$, Ishan Aditya $\mathrm{BHSc}^{7}$, Yonah Krakowsky $\mathrm{MD}^{8}$, Aristithes

G. Doumouras MD MPH ${ }^{2,3}$, Scott Gmora MD ${ }^{2,3}$, Mehran Anvari MBBS PhD ${ }^{2,3}$, Dennis Hong $\operatorname{MD~} \mathrm{MSc}^{2,3 *}$

\section{Author affiliations:}

${ }^{1}$ Michael G. DeGroote School of Medicine, McMaster University, Hamilton, Ontario,

Canada.

${ }^{2}$ Division of General Surgery, Department of Surgery, McMaster University, Hamilton, Ontario, Canada.

${ }^{3}$ Centre for Minimal Access Surgery (CMAS), St. Joseph's Healthcare, McMaster University, Hamilton, Ontario, Canada.

${ }^{4}$ Departments of Urology and Public Health, University of Helsinki and Helsinki University Hospital, Helsinki, Finland.

I nis artıcie nas been accepted Ior pubıcation and undergone ruil peer review but nas not been through the copyediting, typesetting, pagination and proofreading process, which may lead to differences between this version and the Version of Record. Please cite this article as doi: $10.1111 /$ bju. 14829

This article is protected by copyright. All rights reserved. 
${ }^{5}$ 2nd Department of General Surgery, Jagiellonian University, Krakow, Poland.

${ }^{6}$ Centre for Research, Training and Innovation in Surgery (CERTAIN Surgery), Krakow, Poland.

${ }^{7}$ Faculty of Medicine, University of Toronto, Toronto, Ontario, Canada.

${ }^{8}$ Division of Urology, Department of Surgery, University of Toronto, Women's College

Hospital and Sinai Health System, Toronto, ON, Canada.

\section{Address all correspondence to (*):}

Dennis Hong, MD, MSc, FRCSC, FACS

Division of General Surgery

Department of Surgery, McMaster University

St. Joseph's Healthcare

50 Charlton Avenue East

Hamilton, Ontario, L8N 4A6, Canada.

Email: dennishong70@gmail.com

Phone: (905) 522-1155 Ext. 32938

Fax: (905) 521-6123

Source of funding: None.

Category: Reviews (systematic review and meta-analysis).

\section{Conflict of interest:}

Yung Lee, James Yu, Kari A.O. Tikkinen, Michał Pędziwiatr, Piotr Major, Ishan Aditya, Yonah Krakowsky, Aristithes G. Doumouras, Scott Gmora, Mehran Anvari, and Dennis Hong have no conflict of interest to declare. 


\begin{abstract}
:
Objectives: To systematically review and meta-analyze the impact of bariatric surgery on obese patients with urinary incontinence (UI).

Methods: A search of Medline, EMBASE, CENTRAL, and PubMed to June 2018 was performed using methods pre-published on PROSPERO. Reporting followed the Preferred Reporting Items for Systematic Review and Meta-analysis guidelines. Studies comparing UI status in obese patients before and after bariatric surgery were included. Primary outcomes were the improvement or complete resolution of any UI, stress urinary incontinence (SUI), and urgency urinary incontinence (UUI). Secondary outcomes were validated UI questionnaire scores. The GRADE approach assessed overall quality of evidence. Results: 33 cohort studies (2,910 patients) were included (median follow-up 12 months). Bariatric surgery resulted in improvement or resolution of any UI in 56\% (95\% confidence interval [CI] 48-63\%), SUI in 47\% (95\% CI 34-60\%), and UUI in 53\% (95\% CI 32-73\%) of patients. Moreover, bariatric surgery significantly decreased $(P<0.001)$ questionnaire scores such as Urogenital Distress Inventory (UDI) by 13.4 points (95\% CI 7.2-19.6), International Consultation on Incontinence Questionnaire (ICIQ) by 4.0 points (95\% CI 2.3-5.7), and Incontinence Impact Questionnaire (IIQ) by 5.3 points (95\% CI 3.9-6.6). However, worsening or new onset of UI was present in 3\% of patients. Quality of evidence was very low for all outcomes.
\end{abstract}

Conclusion: Half of obese patients report improvement or resolution of UI after bariatric surgery, but overall quality of evidence is very low. Comparative studies examining the benefits of bariatric surgery in obese patients with UI are warranted.

Keywords: Bariatric surgery, Obesity, Urinary incontinence, Stress urinary incontinence, Urge urinary incontinence 


\section{Introduction}

Urinary incontinence (UI) decreases quality of life, creates emotional distress, and imposes economic burden for hundreds of million people worldwide (1). The International Continence Society and International Urogynecological Association defines UI as the involuntary loss of urine, stress urinary incontinence (SUI) as the involuntary loss of urine on effort or physical exertion, or on sneezing or coughing, and urgency urinary incontinence (UUI) as the involuntary loss of urine associated with a sudden and compelling desire to pass urine (2). From an individual perspective, UUI is the most bothersome symptom in both genders, and from societal perspective, SUI is the most burdensome of all urinary symptoms in women (3).

Obesity is a major risk factor for UI. Obesity affects more than one third of adults in the United States and is predicted to affect $51.1 \%$ by 2030 based on current trends (4). Every 5-point increase in body mass index (BMI) has been associated with a 30 to $60 \%$ increased odds of UI over 5 to 10 years (5). Mechanistically, central adiposity in patients with obesity may increase intra-abdominal pressure, intravesical pressure, and urethral mobility, causing UI (6). All patients with UI may benefit from pelvic floor muscle training, bladder training, and weight loss, but traditionally, SUI is treated surgically while UUI can be treated with pharmacotherapy including antimuscarinics $(7,8)$. The European Association of Urology gives a strong recommendation for obese adults with UI to lose weight and maintain it, however, long-term weight loss of at least $10 \%$ is only maintained in an estimated 20 to $30 \%$ of people who undertake lifestyle interventions (9).

Bariatric surgery is the most effective form of sustained weight loss in patients with obesity (10). Earlier studies have also reported a decreased prevalence of UI in obese patients, even years after bariatric surgery (11-16). Despite the increasing evidence investigating the effect of bariatric surgery on UI, no quantitative synthesis exists. 
Unfortunately, studies commonly use a wide range of questionnaires and outcome measures to evaluate UI, making comparisons difficult, and complicating the assessment of bariatric surgery on specific types of UI (12-19).

UI is not currently a prerequisite for bariatric surgery in patients with clinically severe obesity according to the National Institutes of Health consensus statement (20). As UI is common among bariatric surgery patients, and as the improvement of obesity-related comorbidities is often the motivating factor encouraging patients to pursue bariatric surgery, it would be crucial the know its impact on UI (21). We therefore performed a systematic review and meta-analysis to establish the effects of bariatric surgery on UI.

\section{Methods}

Search strategy

We comprehensively searched the following databases from database inception through June $9^{\text {th }}$, 2018: Medline, EMBASE, Web of Science, Cochrane Central Register of Controlled Trials (CENTRAL), and PubMed. The search was designed and conducted by a medical research librarian with input from study investigators (complete search strategy available in Supplementary Table 1). We searched abstracts published from annual meetings of International Urogynecological Association (1999-2014) and International Incontinence Society (1999-2014). We did not discriminate full texts by language. This systematic review and meta-analysis is conducted and reported in accordance with the Meta-analyses Of Observational Studies in Epidemiology (MOOSE) (22). The protocol of this study was registered before commencement in the Prospective Register of Systematic Reviews (PROSPERO CRD42018106900). 


\section{Outcomes assessed}

Primary outcomes included complete resolution or improvement of any UI, SUI, and UUI after bariatric surgery. While the exact definition of complete resolution or improvement varied between studies, most studies evaluated it using questions from validated questionnaires. Secondary outcomes were: (1) Other measures of UI (voids per day, episodes of nocturia per week, UI episodes per day, and pad use per day) (2) worsening of UI after bariatric surgery (3) adverse events after bariatric surgery. Major complications were classified as Clavien-Dindo complication classification grade III or above (conditions requiring surgical, radiological, and endoscopic intervention, organ dysfunction, or death) (23).

\section{Study Selection and Data extraction}

Articles were included if they examined the effect of bariatric surgery on any UI, including SUI and UUI in patients with class 2 obesity or higher $\left(\mathrm{BMI}>35 \mathrm{~kg} / \mathrm{m}^{2}\right)$. Due to the heterogeneity present in the definition of UI, we accepted the definition of UI in each study as long as it captured the patient's own perception of incontinence (24). Studies were eligible for inclusion if they were cohort studies (prospective or retrospective) and randomized controlled trials. Letters, editorials, case-reports, case-series, and review papers were excluded. We included both single-arm studies (effect of bariatric surgery on UI before and after surgery without a comparator) or double-arm studies (bariatric surgery versus medical therapy or no surgery). We excluded studies with fewer than 10 eligible patients.

Two reviewers independently evaluated the systematically searched titles and abstract using a standardized, pilot-tested form. Discrepancies that occurred at the title and abstract screening stages were resolved by automatic inclusion to ensure relevant papers were not missed. Discrepancies at the full-text stage were resolved by consensus between two 
reviewers and if disagreement persisted, a third reviewer was consulted. Two reviewers independently conducted data abstraction onto a data collection manual designed a priori. Abstracted data included study characteristics (eg. author, year of publication, study design, funding source) patient demographics (eg. age, \% female, preoperative and postoperative BMI, \% diabetes, type of bariatric surgery), UI assessment description (eg. validated UI questionnaire used, type of survey, type of UI assessed), and outcomes. For studies reporting multiple follow-up time points, we analyzed the time point closest to one year. This was because previous studies of UI, including the largest observational cohort to date by Subak et al., have found that weight loss and the improvement and resolution of UI peak one year after bariatric surgery, and decline afterwards (11). In the case of Subak et al., the one year prevalence of UI was $18.3 \%$ in women and $9.8 \%$ in men, while the three year prevalence increased to $24.8 \%$ in women and $12.2 \%$ in men, with the increase attributed to the lack of continued follow-up (11).

\section{Risk of Bias Assessment and Certainty of Evidence}

A post-hoc decision was made to use a UI-specific risk of bias tool for nonrandomized studies that was previously reported in the literature (24). Risk of bias for each study was assessed using six criteria, modified from a novel risk of bias tool for UI: sampling and representativeness of population, assessment of exposure, assessment of outcome, presence of UI at the start of the study, adjustment for confounding, and missing data (Supplementary Table 2) (24). Each criterion was rated low or high risk of bias and studies with at least two "high risk of bias" criteria were classified as high risk of bias overall. Quality of evidence for estimates derived from meta-analyses were assessed by GRADE (Grading of Recommendations, Assessment, Development and Evaluation) (25).

\section{Data Synthesis and Analysis}


All statistical analysis and meta-analysis were performed on STATA, version 14 (StataCorp, College, TX) and Cochrane Review Manager 5.3 (London, United Kingdom). Scores for Urogenital Distress Inventory (UDI) and Incontinence Impact Questionnaire (IIQ) questionnaires were converted using previously determined formulas to UDI-7 and IIQ-7 respectively (26). The threshold for statistical significance was set $a$ priori at alpha $=0.05$. The pooled proportion of patients with improvement or complete resolution of UI after bariatric surgery was calculated using the Freeman-Tukey double arcsine transformation of proportions. DerSimonian and Laird random effects meta-analysis of proportions was used to generate the overall effect size of each outcome. The same method was applied for worsening of UI after bariatric surgery. We performed pairwise meta-analyses using a DerSimonian and Laird random effects model for continuous variables before and after bariatric surgery. Pooled effect estimates were obtained by calculating the mean difference (MD) in outcomes along with their respective $95 \%$ confidence intervals (CI) to confirm the effect size estimation. Assessment of heterogeneity was completed using the inconsistency $\left(\mathrm{I}^{2}\right)$ statistic. We considered $\mathrm{I}^{2}$ higher than $50 \%$ to represent considerable heterogeneity (27). For significant outcomes, a leave-one-out sensitivity analysis was performed by removing one study at a time to confirm that our findings were not driven by any single study. Publication bias was assessed using a funnel plot. In addition, we performed subgroup analyses based on different types of UI.

\section{Results}

\section{Study Characteristics}

From 817 potentially relevant reports, 35 studies (all observational; no randomized trials) were eligible $(12,13,29-38,14,39-48,15,49-52,16-19,21,28)$. Of these 35 , we excluded two studies in this systematic review: Shimonov et al. and Leshem et al. $(40,48)$. These 
studies were excluded because their study cohort were nearly identical, and we suspected they included members of the same cohort and decided to avoid double counting of patients. Figure 1 represents a detailed PRISMA flow diagram of study selection process. Included studies were conducted between 1988 and 2018, with median follow-up of 12 months (range 6 to 60 months) after bariatric surgery. The weighted mean BMI before surgery was $46.0 \pm$ $2.8 \mathrm{~kg} / \mathrm{m}^{2}$ and $32.2 \pm 2.4 \mathrm{~kg} / \mathrm{m}^{2}$ at follow-up, with absolute percent reduction of $30 \%$.

Table 1 presents descriptions of the 33 included studies. Table 2 provides each authors' definition of SUI and UUI, and descriptions of validated questionnaires used to assess UI. A wide range of 14 different UI questionnaires were used across included studies (complete list of UI questionnaires is available in Supplementary Table 3). Some studies did not clarify the method used to assess UI, but still reported UI status before and after surgery based on interviewing patients $(19,29,33,35,45,52)$. Bariatric surgeries conducted in the included studies were Roux-en-Y gastric bypass (RYGB, 20 studies), Sleeve Gastrectomy (SG, 16 studies), Laparoscopic Adjustable Gastric Bypass (LAGB, 11 studies), One Anastomosis Gastric Bypass (OAGB, 1 study), Banded Gastric Bypass (BGB, 1 study), Vertical Banded Gastroplasty (VBG. 1 study), Biliopancreatic Diversion with Duodenal Switch (BPD-DS, 2 study), Horizontal Gastroplasty (1 study), and Jejunoileal Bypass (JIB, 1 study).

\section{Effect of bariatric surgery on improvement of UI}

From the 33 studies included, 30 studies reported any UI $(n=2,772), 13$ reported SUI $(\mathrm{n}=1,186)$, and 8 reported UUI $(\mathrm{n}=720)$ before and after bariatric surgery. Meta-analysis of proportions demonstrated a resolution or improvement of any UI in 56\% (95\% CI 48-63\%) of patients, SUI in 47\% (95\% CI 34-60\%), and UUI in 53\% (32-73\%) of patients after bariatric surgery (Figure 2A-C). Complete resolution of any UI was seen in $48 \%$ (39-57\%), 
SUI in 39\% (24-55\%), and UUI in 55\% (29-80\%) (Supplementary Figure 1A-C). A list of outcomes for UI reported in individual studies can be found in Supplementary Table 4A-C. Heterogeneity was high across all outcomes ranging from $\mathrm{I}^{2}$ of 87.6 to $96.3 \%$. Subgroup analyses based on type of bariatric surgery were not possible because in most studies more than one type of bariatric surgeries was conducted but results were not reported separately.

\section{Scores of validated questionnaires after bariatric surgery}

Similar to the overall improvement and resolution of UI, bariatric surgery resulted in a significant decrease in several UI questionnaire scores. The most commonly reported questionnaires were UDI, International Consultation on Incontinence Questionnaire (ICIQ), IIQ, and Pelvic Organ Prolapse/UI Sexual Questionnaire (PISQ) (Supplementary Table 3). Bariatric surgery resulted in a significant decrease in UDI scores by 13.4 points (95\% CI 7.2 to $19.6, P=<.001$ ), ICIQ by 4.0 points ( 2.3 to $5.7, P=<.001$ ), and IIQ by 5.3 points ( 3.9 to $6.6, P=<.001)$. In contrast, there was no significant difference in PISQ scores (MD -0.3, - 2.4 to $1.8, P=0.78$ ) (Figure 3A-D). Other UI questionnaires and their scores were sparsely reported, or raw scores were not reported and therefore were not meta-analyzed. Sensitivity analyses across all outcomes did not affect the pooled estimates or significance of the results.

\section{Narrative summary of other UI outcomes}

Although four measures of UI (voids per day, episodes of nocturia per week, UI episodes per day, and pad use per day) were not meta-analyzed due to being reported in a small number of studies or due to incomplete data, there appeared to be improvements in all four measures. All three studies reporting the number of voids per day before and after 
bariatric surgery found improvements, with Palleschi et al. reporting that in 120 patients, voids decreased from a mean of 9.6 per day before surgery to 6.6 per day following surgery $(36,44,52)$. Two studies reporting episodes of nocturia per week both found improvements, with Palleschi et al. reporting that episodes of nocturia decreased from 16.1 per week to 7.7 per week after bariatric surgery $(44,52)$. Both studies reporting pad use per day also found improvements with Daucher et al. reporting that pad use decreased from 3.5 per day to 1.75 per day after bariatric surgery $(36,52)$. All three studies examining incontinence episodes per day found improvements with Bump et al. reporting that episodes decreased from 1.91 per day to 0.13 per day after bariatric surgery $(36,44,52)$.

Adverse events

Worsening or new onset of UI was reported in only 8 (24\%) out of 33 studies $(\mathrm{n}=1,302)$. In total, 2 patients reported worsening of UUI (17), 2 patients reported worsening SUI (45), and 54 patients reported worsening or new onset of any UI. Meta-analysis of proportions demonstrated that worsening or new onset of UI occurs in 3\% (95\% 0-14\%) (Figure 2D). Adverse events related to bariatric surgeries were only reported in 5 (15\%) studies. In these studies, among 1,007 patients, there were 33 (3\%) major complications related to bariatric surgery including $3(0.3 \%)$ deaths, $7(0.7 \%)$ band slippages or erosions, 12 (1\%) bowel obstructions, $9(0.9 \%)$ hernias, $3(0.3 \%)$ strictures, and $1(0.1 \%)$ staple line leak (Supplementary Table 5). 
Risk of Bias Assessment and Quality of Evidence

All studies included in this review drew patients from their chosen database over the same time frame, and we judged there to be low risk of bias for sampling and representativeness of the population. In 11 studies (31\%), it was uncertain how much BMI changed after surgery or BMI was not assessed in person. 18 studies (51\%) either did not report how many patients had UI at the beginning and end of the study or did not explicitly exclude confounders. 21 studies $(60 \%)$ had little missing data with high proportions of patients reporting data at baseline and follow-up. 8 studies (23\%) adjusted or matched for all important confounders including BMI, age, and parity. 22 studies (63\%) used self-reported validated questionnaires or another method with demonstrated validity (Supplementary Table 6). The GRADE quality of evidence profile is summarized on Table 3. Because of the high loss to follow up and the presence of confounders, the evidence was rated down for serious risk of bias for all outcomes. The evidence was rated down for inconsistency in all outcomes except IIQ due to high heterogeneity. Due to the low number of participants with outcomes reported for PISQ, the evidence was rated down for imprecision. While there was a large magnitude of effect for the improvement or complete resolution of any UI, SUI, and UUI, the certainty was not upgraded because of major concerns with risk of bias and inconsistency (53). Overall, there was a very low certainty of evidence suggesting the effect of estimate is uncertain. Symmetry shown in our funnel plot suggests that there is a low possibility of publication bias, meaning that there may be a low number of unpublished negative studies (Supplementary Figure 2).

This article is protected by copyright. All rights reserved. 


\section{Discussion}

This is the most comprehensive systematic review and meta-analysis investigating the effect of bariatric surgery on UI to date. The current evidence suggests that bariatric surgery results in the improvement or resolution of any UI in 56\% (95\% CI 48-63\%), SUI in 47\% (95\% CI 34-60\%), and UUI in 53\% (95\% CI 32-73\%) of patients. Complementing the objective improvements in UI, this review also demonstrated improvements in quality of life and patient-perceived symptoms of UI. Bariatric surgery significantly $(P=<.001)$ decreased UDI scores by 13.41 points (95\% CI 7.2-19.6), ICIQ score by 4.00 points (95\% CI 2.3-5.7), and IIQ scores by 5.28 points (95\% CI 3.9-6.6) after surgery (very low-quality evidence). Conversely, 3\% (95\% CI 0-14\%) of patients experienced worsening or new onset of UI after surgery. These data suggest that patients undergoing bariatric surgery may experience substantial improvements in UI.

Previous meta-analyses have been conducted exploring the impact of bariatric surgery on UI. Reviews by Lian et al. and Zhang et al. included 11 and 10 cohort studies respectively compared to the 33 cohort studies in the present study $(54,55)$. Furthermore, their reviews did not separately analyze SUI and UUI, making it uncertain what group of patients with UI would benefit from bariatric surgery as the causes of SUI and UUI differ. The present review also differs from previous reviews in its rigorous assessment of included studies. While the protocol specified that the methodological index for non-randomized studies (MINORS) instrument would be used to evaluate of risk of bias on the individual study level, a post-hoc decision was made to instead use a modified tool specifically designed for UI that was previously reported in the literature.(24) Risk of bias on the body of evidence level was also evaluated using GRADE $(54,55)$. The findings of the present review also agree with wellperformed previous studies exploring the effect of both weight loss and bariatric surgery on 
UI. In a recent large prospective cohort study of bariatric surgery patients with follow-up of 1 year after surgery, the prevalence of UI decreased from 49 to $18 \%$ in women and from 21 to $10 \%$ in men (11).

The results of this review are encouraging as UI is present in 60 to $70 \%$ of obese women with a BMI above $40 \mathrm{~kg} / \mathrm{m}^{2}$ who are considering bariatric surgery $(28,35,56)$. The minimal important differences (MID) for ICIQ-UI is previously reported to be a decrease of 5 points at 12 months (57). While the MID for UDI-6 and IIQ-7 are not available, the MID for their parent questionnaires range from -22.4 to -6.4 points for UDI and -16.5 to -4.6 points for UIQ (58). Therefore, the improvements in the ICIQ-UI, UDI-6, and IIQ-7 scores in the present review appear to be within the range of error for the MID and may result in important improvements in UI for patients. Considering the present review suggests that bariatric surgery may improve UI in a significant proportion of obese patients with associated improvements in quality of life, morbidly obese patients seeking treatment for UI may benefit from discussing possible surgical and non-surgical interventions with both their urologist and a bariatric surgeon. While common surgical, pharmacological and behavioral treatments for UI target incontinence alone, bariatric surgery has been demonstrated to improve or resolve a variety of comorbidities including diabetes, which increases urination, and contributes to the development of UI (59). Given the wide range of benefits associated with bariatric surgery, it may warrant consideration to treat obese patients with UI and open to bariatric surgery, with bariatric surgery first, before determining whether further treatments such as midurethral slings for UI are required. Although the overall certainty of evidence is very low for all outcomes, obese patients with UI can still reasonably be counseled on the potential benefits of weight loss from bariatric surgery. 
The findings in our study should be interpreted in light of the following limitations. First, all studies were observational with no comparators, leading to a very low certainty of evidence in all outcomes. No RCTs examining the effect of bariatric surgery on UI were found in the literature. Heterogeneity between included studies was high for many outcomes including UDI and ICIQ. Although we conducted sensitivity analyses to address this heterogeneity, our results failed to explain why heterogeneity was present across pooled effect estimates. Moreover, if there were enough studies exclusively reporting one type of bariatric surgery and its impact on UI, a subgroup analysis would have been possible to reveal the difference in UI outcomes between surgeries (e.g. LSG versus RYGB). Potential causes could include the wide range of follow-up time points across included studies, the variety of surgeries used, or other comorbidities at an individual patient level. Unfortunately, there is no definitive quantitative tool to measure UI, and studies reported a wide range of questionnaires, including the Sandvik severity score and Bristol Female Lower Urinary Tract Symptoms (BFLUTS) questionnaires which were not reported in enough studies to warrant meta-analysis $(16,17,60)$. In many studies, data on the improvement and resolution of UI was drawn from validated questionnaires rather than urodynamic assessments. While self-reported questionnaire data may be influenced by recall bias, we consider the self-reporting of UI the most patient-important outcome. The definition of UI and specific questions asked to participants also slightly varied amongst studies, potentially explaining some of the heterogeneity in the improvement and resolution of UI, SUI, and UUI. Worsening or new onset of UI was also only reported by 8 out of 33 studies, creating the possibility that any harms of bariatric surgery on UI were not unreported or even underestimated.

In conclusion, a very low certainty of evidence exists that bariatric surgery leads to improvement or resolution of UI in half of patients, making it a potentially useful strategy for management of UI in obese patients. Further large-scale studies with a standardized method 
of reporting UI outcomes are warranted to confirm the therapeutic benefits of bariatric surgery on UI.

\section{Acknowledgement}

The authors wish to thank Dr. Stefan Schandelmeier and Dr. Vahid Ashoorion for their insights on research methods and utilizing Grading of Recommendations, Assessment, Development, and Evaluation (GRADE) for this review, Ms. Laura Banfield, medical/health librarian for her assistance with the search strategy.

\section{References}

1. Irwin DE, Kopp ZS, Agatep B, Milsom I, Abrams P. Worldwide prevalence estimates of lower urinary tract symptoms, overactive bladder, urinary incontinence and bladder outlet obstruction. BJU Int. 2011 Oct;108(7):1132-8.

2. Haylen BT, de Ridder D, Freeman RM, Swift SE, Berghmans B, Lee J, et al. An International Urogynecological Association (IUGA)/International Continence Society (ICS) joint report on the terminology for female pelvic floor dysfunction. Int Urogynecol J. 2010 Jan 25;21(1):5-26.

3. Agarwal A, Eryuzlu LN, Cartwright R, Thorlund K, Tammela TLJ, Guyatt GH, et al. What is the most bothersome lower urinary tract symptom? Individual- and population-level perspectives for both men and women. Eur Urol. 2014;

This article is protected by copyright. All rights reserved. 
4. Wang Y, Beydoun MA, Liang L, Caballero B, Kumanyika SK. Will All Americans Become Overweight or Obese? Estimating the Progression and Cost of the US Obesity Epidemic. Obesity. 2008 Oct;16(10):2323-30.

5. Subak LL, Richter HE, Hunskaar S. Obesity and Urinary Incontinence: Epidemiology and Clinical Research Update. J Urol. 2009 Dec;182(6):S2-7.

6. Noblett KL, Jensen JK, Ostergard DR. The relationship of body mass index to intraabdominal pressure as measured by multichannel cystometry. Int Urogynecol J Pelvic Floor Dysfunct. 1997;8(6):323-6.

7. Qaseem A, Dallas P, Forciea MA, Starkey M, Denberg TD, Shekelle P. Nonsurgical Management of Urinary Incontinence in Women: A Clinical Practice Guideline From the American College of Physicians. Ann Intern Med. 2014 Sep;161(6):429.

8. Subak LL, Wing R, West DS, Franklin F, Vittinghoff E, Creasman JM, et al. Weight Loss to Treat Urinary Incontinence in Overweight and Obese Women. N Engl J Med. 2009 Jan;360(5):481-90.

9. Mosca L, Barrett-Connor E, Wenger NK, Collins P, Grady D, Kornitzer M, et al. Design and methods of the Raloxifene Use for The Heart (RUTH) study. Am J Cardiol. 2001;88(4):392-5.

10. Adams TD, Davidson LE, Litwin SE, Kim J, Kolotkin RL, Nanjee MN, et al. Weight and Metabolic Outcomes 12 Years after Gastric Bypass. N Engl J Med. 2017 Sep;377(12):1143-55.

11. Subak LL, King WC, Belle SH, Chen J-Y, Courcoulas AP, Ebel FE, et al. Urinary Incontinence Before and After Bariatric Surgery. JAMA Intern Med. 2015 
Aug;175(8):1378-87.

12. Ranasinghe WKB, Wright T, Attia J, McElduff P, Doyle T, Bartholomew M, et al. Effects of bariatric surgery on urinary and sexual function. BJU Int. 2011 Jan;107(1):88-94.

13. Ait Said K, Leroux Y, Menahem B, Doerfler A, Alves A, Tillou X. Effect of bariatric surgery on urinary and fecal incontinence: prospective analysis with 1-year follow-up. Surg Obes Relat Dis. 2017 Feb;13(2):305-12.

14. Laungani RG, Seleno N, Carlin AM. Effect of laparoscopic gastric bypass surgery on urinary incontinence in morbidly obese women. Surg Obes Relat Dis. 2009 May;5(3):334-8.

15. Romero-Talamás H, Unger CA, Aminian A, Schauer PR, Barber M, Brethauer S. Comprehensive evaluation of the effect of bariatric surgery on pelvic floor disorders. Surg Obes Relat Dis. 2016 Jan;12(1):138-43.

16. Kuruba R, Almahmeed T, Martinez F, Torrella TA, Haines K, Nelson LG, et al. Bariatric surgery improves urinary incontinence in morbidly obese individuals. Surg Obes Relat Dis. 2007 Nov;3(6):586-90.

17. Leshem A, Groutz A, Amir H, Gordon D, Shimonov M. Surgically induced weight loss results in a rapid and consistent improvement of female pelvic floor symptoms. Scand J Urol. 2018 Mar;1-6.

18. Knepfler T, Valero E, Triki E, Chilintseva N, Koensgen S, Rohr S. Bariatric surgery improves female pelvic floor disorders. J Visc Surg. 2016 Apr;153(2):95-9.

19. Schouten R, van Dijke JCM, van 't Hof G, Feskens PBGM. Prevalence and Risk 
Factors of Urinary Incontinence and Bladder Retention in Gastric Bypass Surgery: a Cross-Sectional Study. Obes Surg. 2013 Jun;23(6):760-3.

20. NIH conference. Gastrointestinal surgery for severe obesity. Consensus Development Conference Panel. Ann Intern Med. 1991 Dec;115(12):956-61.

21. O'Boyle CJ, O'Sullivan OE, Shabana H, Boyce M, O'Reilly BA. The Effect of Bariatric Surgery on Urinary Incontinence in Women. Obes Surg. 2016 Jul;26(7):1471-8.

22. Stroup DF, Berlin JA, Morton SC, Olkin I, Williamson GD, Rennie D, et al. Metaanalysis of Observational Studies in Epidemiology: A Proposal for Reporting. JAMA. 2000 Apr;283(15):2008.

23. Clavien PA, Barkun J, De Oliveira ML, Vauthey JN, Dindo D, Schulick RD, et al. The clavien-dindo classification of surgical complications: Five-year experience. Annals of Surgery. 2009.

24. Tähtinen RM, Cartwright R, Tsui JF, Aaltonen RL, Aoki Y, Cárdenas JL, et al. Longterm Impact of Mode of Delivery on Stress Urinary Incontinence and Urgency Urinary Incontinence: A Systematic Review and Meta-analysis. Eur Urol. 2016 Jul;70(1):14858.

25. Guyatt GH, Oxman AD, Vist GE, Kunz R, Falck-Ytter Y, Alonso-Coello P, et al. GRADE: an emerging consensus on rating quality of evidence and strength of recommendations. BMJ. 2008 Apr;336(7650):924-6.

26. Barber MD, Chen Z, Lukacz E, Markland A, Wai C, Brubaker L, et al. Further validation of the short form versions of the Pelvic Floor Distress Inventory (PFDI) and 
Pelvic Floor Impact Questionnaire (PFIQ). Neurourol Urodyn. 2011 Apr;30(4):541-6.

27. Higgins JPT, Thompson SG, Deeks JJ, Altman DG. Measuring inconsistency in metaanalyses. BMJ Br Med J. 2003;327(7414):557-60.

28. Burgio KL, Richter HE, Clements RH, Redden DT, Goode PS. Changes in Urinary and Fecal Incontinence Symptoms With Weight Loss Surgery in Morbidly Obese Women. Obstet Gynecol. 2007 Nov;110(5):1034-40.

29. Ahroni JH, Montgomery KF, Watkins BM. Laparoscopic Adjustable Gastric Banding: Weight Loss, Co-morbidities, Medication Usage and Quality of Life at One Year. Obes Surg. 2005 May;15(5):641-7.

30. Bulbuller N, Habibi M, Yuksel M, Ozener O, Oruc MT, Oner OZ, et al. Effects of bariatric surgery on urinary incontinence. Ther Clin Risk Manag. 2017;13:95-100.

31. Whitcomb EL, Horgan S, Donohue MC, Lukacz ES. Impact of surgically induced weight loss on pelvic floor disorders. Int Urogynecol J. 2012 Aug;23(8):1111-6.

32. Castro LA de, Sobottka W, Baretta G, Freitas ACT de. Effects of bariatric surgery on pelvic floor function. Arq Bras Cir Dig. 25(4):263-8.

33. Choi J, Digiorgi M, Milone L, Schrope B, Olivera-Rivera L, Daud A, et al. Outcomes of laparoscopic adjustable gastric banding in patients with low body mass index. Surg Obes Relat Dis. 2010 Jul;6(4):367-71.

34. Cuicchi D, Lombardi R, Cariani S, Leuratti L, Lecce F, Cola B. Clinical and instrumental evaluation of pelvic floor disorders before and after bariatric surgery in obese women. Surg Obes Relat Dis. 2013 Jan;9(1):69-75. 
35. Deitel M, Stone E, Kassam HA, Wilk EJ, Sutherland DJ. Gynecologic-obstetric changes after loss of massive excess weight following bariatric surgery. J Am Coll Nutr. 1988 Apr;7(2):147-53.

36. Daucher JA, Ellison RE, Lowder JL. Pelvic Support and Urinary Function Improve in Women After Surgically Induced Weight Reduction. Female Pelvic Med Reconstr Surg. 2010 Sep;16(5):263-7.

37. Gabriel I, Tavakkoli A, Minassian VA. Pelvic Organ Prolapse and Urinary Incontinence in Women After Bariatric Surgery. Female Pelvic Med Reconstr Surg. 2018;24(2):120-5.

38. Kim JH, Sun HY, Lee HY, Soh MJ, Park S, Kim YJ, et al. Improvement of voiding characteristics in morbidly obese women after bariatric surgery: A single-center study with a 1-year follow-up. Surg Obes Relat Dis. 2017 May;13(5):836-41.

39. Knoepp LR, Semins MJ, Wright EJ, Steele K, Shore AD, Clark JM, et al. Does Bariatric Surgery Affect Urinary Incontinence? Urology. 2013 Sep;82(3):547-51.

40. Leshem A, Shimonov M, Amir H, Gordon D, Groutz A. Effects of Bariatric Surgery on Female Pelvic Floor Disorders. Urology. 2017 Jul;105:42-7.

41. Maher JW, Martin Hawver L, Pucci A, Wolfe LG, Meador JG, Kellum JM. Four Hundred Fifty Consecutive Laparoscopic Roux-en-Y Gastric Bypasses with No Mortality and Declining Leak Rates and Lengths of Stay in a Bariatric Training Program. J Am Coll Surg. 2008 May;206(5):940-4.

42. McDermott CD, Terry CL, Mattar SG, Hale DS. Female Pelvic Floor Symptoms Before and After Bariatric Surgery. Obes Surg. 2012 Aug;22(8):1244-50. 
43. Olivera CK, Herron DM, Kini SU, Vardy MD, Ascher-Walsh CJ, Garely AD, et al. Long-term quality of life and pelvic floor dysfunction after bariatric surgery. Am J Obstet Gynecol. 2012 Nov;207(5):431.e1-431.e4.

44. Palleschi G, Pastore AL, Rizzello M, Cavallaro G, Silecchia G, Carbone A. Laparoscopic sleeve gastrectomy effects on overactive bladder symptoms. J Surg Res. 2015 Jun;196(2):307-12.

45. Roberson EN, Gould JC, Wald A. Urinary and Fecal Incontinence After Bariatric Surgery. Dig Dis Sci. 2010 Sep;55(9):2606-13.

46. Scozzari G, Rebecchi F, Giaccone C, Chiaro P, Mistrangelo M, Morino M. Bariatric Surgery Improves Urinary Incontinence but Not Anorectal Function in Obese Women. Obes Surg. 2013 Jul;23(7):931-8.

47. Srinivasa S, Hill LS, Sammour T, Hill AG, Babor R, Rahman H. Early and Mid-term Outcomes of Single-Stage Laparoscopic Sleeve Gastrectomy. Obes Surg. 2010 Nov;20(11):1484-90.

48. Shimonov M, Groutz A, Schachter P, Gordon D. Is bariatric surgery the answer to urinary incontinence in obese women? Neurourol Urodyn. 2017 Jan;36(1):184-7.

49. Uruç F, Akan S, Aras B, Yıldırım Ç, Sahin A, Yuksel OH, et al. Effects of obesity surgery (laparoscopic sleeve gastrectomy technique) on lower urinary tract symptoms, depression and quality of life of males: Prospective study. Arch Ital di Urol e Androl. 2016 Dec;88(4):258.

50. Vella VL, Jaffe W, Lidicker J, Meilahn J, Dandolu V. Prevalence of urinary symptoms in morbidly obese women and changes after bariatric surgery. J Reprod Med. 2009 
Oct;54(10):597-602.

51. Wasserberg N, Petrone P, Haney M, Crookes PF, Kaufman HS. Effect of Surgically Induced Weight Loss on Pelvic Floor Disorders in Morbidly Obese Women. Ann Surg. 2009 Jan;249(1):72-6.

52. Bump RC, Sugerman HJ, Fantl JA, McClish DK. Obesity and lower urinary tract function in women: effect of surgically induced weight loss. Am J Obstet Gynecol. 1992 Aug;167(2):392-7; discussion 397-9.

53. Guyatt GH, Oxman AD, Sultan S, Glasziou P, Akl EA, Alonso-Coello P, et al. GRADE guidelines: 9. Rating up the quality of evidence. J Clin Epidemiol. 2011;64(12):1311-6.

54. Zhang J, Gao L, Liu M, Liu C. Effect of Bariatric Surgery on Urinary Incontinence in Obese Women. Female Pelvic Med Reconstr Surg. 2018 Aug;1.

55. Lian W, Zheng Y, Huang H, Chen L, Cao B. Effects of bariatric surgery on pelvic floor disorders in obese women: a meta-analysis. Arch Gynecol Obstet. 2017 Aug;296(2):181-9.

56. Richter HE, Burgio KL, Clements RH, Goode PS, Redden DT, Varner RE. Urinary and anal incontinence in morbidly obese women considering weight loss surgery. Obstet Gynecol. 2005 Dec;106(6):1272-7.

57. Sirls LT, Tennstedt S, Brubaker L, Kim H-Y, Nygaard I, Rahn DD, et al. The minimum important difference for the International Consultation on Incontinence Questionnaire-Urinary Incontinence Short Form in women with stress urinary incontinence. Neurourol Urodyn. 2015 Feb;34(2):183-7. 
58. Barber MD, Spino C, Janz NK, Brubaker L, Nygaard I, Nager CW, et al. The minimum important differences for the urinary scales of the Pelvic Floor Distress Inventory and Pelvic Floor Impact Questionnaire. Am J Obstet Gynecol. 2009 May;200(5):580.e1-580.e7.

59. Lawrence JM, Lukacz ES, Liu I-LA, Nager CW, Luber KM. Pelvic floor disorders, diabetes, and obesity in women: findings from the Kaiser Permanente Continence Associated Risk Epidemiology Study. Diabetes Care. 2007 Oct;30(10):2536-41.

60. Lim R, Liong ML, Leong WS, Yuen KH. Which outcome measures should be used in stress urinary incontinence trials? BJU Int. 2018 May;121(5):805-10.

This article is protected by copyright. All rights reserved. 


\section{Figure Legends:}

Figure 1. PRISMA Diagram - transparent reporting of systematic reviews and meta-analysis flow diagram outlining the search strategy results from initial search to included studies

Figure 2. Proportion random-effects meta-analysis forest plot of $\mathbf{A}$, improvement or complete resolution of any urinary incontinence (UI). $\mathbf{B}$, improvement or complete resolution of stress UI. C, improvement or complete resolution of urgency UI. D, worsening or new onset of any UI.

Figure 3. Random effects meta-analysis forest plot of A, Urogenital Distress Inventory (UDI) scores. B, International Consultation on Incontinence Questionnaire (ICIQ). C, Incontinence Impact Questionnaire (IIQ). D, Pelvic Organ Prolapse/UI Sexual Questionnaire (PISQ).

Supplementary Figure 1. Proportion random-effects meta-analysis forest plot of A, resolution of any urinary incontinence (UI). B, resolution of stress UI. C, resolution of urgency UI.

Supplementary Figure 2. Funnel plot testing the presence of publication bias in studies addressing the improvement or resolution of urinary incontinence after bariatric surgery. 


\begin{tabular}{|c|c|c|c|c|c|c|c|c|}
\hline Study & $\mathrm{N}$ analyzed & Surgery & Age & \% Female & Pre-op BMI & Post-op BMI & \% Diabetes & Specific inclusion criteria \\
\hline Ahroni, 2005 & 193 & LAGB & $43.8 \pm 10.1$ & 82.8 & $45.8 \pm 7.7$ & $32.3 \pm 7$ & 15.4 & $\begin{array}{l}\text { NIH criteria or patients with significant medical } \\
\text { co-morbidities that can be improved by weight } \\
\text { loss. }\end{array}$ \\
\hline Bulbuller, 2017 & 120 & LSG & $39.19 \pm 9.94$ & 100 & $46.17 \pm 5.35$ & $31.6 \pm 4.4$ & 30 & Women who met NIH criteria. \\
\hline Bump, 1992 & 13 & RYGB & $41 \pm 11.9$ & 100 & $49.4 \pm 7.9$ & $33.1 \pm 6.7$ & - & $\begin{array}{l}\text { Women at least } 45 \mathrm{~kg} \text { above their ideal body } \\
\text { weight as estimated by } 1983 \text { Metropolitan Life } \\
\text { Insurance tables for medium frame. }\end{array}$ \\
\hline Burgio, 2007 & 92 & LRYGB & $40.2(20-55)$ & 100 & $48.9 \pm 7.2$ & $30.2 \pm 5.7$ & 15.8 & $\begin{array}{l}\text { Women with BMI of } 40 \mathrm{~kg} / \mathrm{m}^{2} \text { or more who } \\
\text { underwent bariatric surgery between October } \\
2003 \text { and February } 2005 \text {. }\end{array}$ \\
\hline Castro, 2012 & 24 & Not specified & $38.83 \pm 7.86$ & 100 & $46.96 \pm 5.77$ & $29.97 \pm 3.48$ & - & $\begin{array}{l}\text { Women with } \mathrm{BMI} \geq 40 \mathrm{~kg} / \mathrm{m}^{2} \text {, and older than } 18 \\
\text { years old. }\end{array}$ \\
\hline Choi, 2010 & 66 & LAGB & $40.7 \pm 11$ & 89.4 & $36.1 \pm 2.6$ & - & 6.5 & $\begin{array}{l}18 \text { to } 65 \text { years old, BMI of } 30-40 \mathrm{~kg} / \mathrm{m}^{2}, \\
\text { reported history of } 3 \text { years of obesity }(\mathrm{BMI}>30 \\
\left.\mathrm{kg} / \mathrm{m}^{2}\right) \text { with failed conservative weight reduction } \\
\text { efforts. }\end{array}$ \\
\hline Cuicchi, 2013 & 87 & RYGB & $\begin{array}{l}42(\text { median }) \\
(20-66)\end{array}$ & 100 & $43.8 \pm 8.5$ & $30 \pm 5.9$ & 12 & $\begin{array}{l}\text { Female patients with BMI of }>30 \mathrm{~kg} / \mathrm{m}^{2} \text { from } \\
\text { March } 2007 \text { to May } 2010 .\end{array}$ \\
\hline Daucher, 2010 & 34 & LRYGB & $47 \pm 9$ & 100 & $46 \pm 6$ & $33 \pm 6$ & - & $\begin{array}{l}\text { Women } 18 \text { years or older scheduled to undergo } \\
\text { weight reductive surgery. }\end{array}$ \\
\hline Deitel, 1988 & 138 & JIB, HG, VBG & $34.8 \pm 8.7$ & 100 & - & - & - & $\begin{array}{l}\text { Women who were morbidly obese and lost more } \\
\text { than } 50 \% \text { of their excess weight following } \\
\text { bariatric surgery. }\end{array}$ \\
\hline Gabriel, 2018 & 447 & LAGB, RYGB, SG & $52.5 \pm 8$ & 100 & - & - & - & $\begin{array}{l}\text { Women who were morbidly obese (BMI, }>40 \\
\mathrm{~kg} / \mathrm{m}^{2} \text { ), over the age of } 35 \text { years and underwent } \\
\text { LAGB, RYGB, or SG. }\end{array}$ \\
\hline Kim, 2017 & 57 & LRYGB & $38.5 \pm 9.5$ & 100 & $37.5 \pm 5.9$ & $28 \pm 4.9$ & - & Women from August to December 2012. \\
\hline Knepfler, 2016 & 70 & LRYGB, SG, GR & $41.4 \pm 11.4$ & 100 & $44.50 \pm 6.31$ & $31.83 \pm 5.83$ & 18.57 & $\begin{array}{l}\text { Obese patients between December } 2012 \text { and } \\
\text { January } 2014 \text { with BMI }>40 \mathrm{~kg} / \mathrm{m}^{2} \text { or a BMI }> \\
35 \mathrm{~kg} / \mathrm{m}^{2} \text { with comorbidities. }\end{array}$ \\
\hline Knoepp, 2013 & 3898 & Any bariatric surgery & $44.5 \pm 0.16$ & 100 & - & - & - & $\begin{array}{l}\text { Female patient undergoing bariatric surgery } \\
\text { within the } 5 \text {-year study period with } \\
\text { postoperative follow-up period of at least } 3 \\
\text { years. }\end{array}$ \\
\hline Kuruba, 2007 & 45 & LRYGB, LAGB & $49 \pm 11$ & 97.78 & $48 \pm 7$ & - & 40 & $\begin{array}{l}\text { Patients who underwent bariatric surgery from } \\
\text { April } 2004 \text { to June } 2006 \text { and reported UI. }\end{array}$ \\
\hline Laungani, 2009 & 58 & LRYGB & $46 \pm 10$ & 100 & $48 \pm 7$ & - & - & Morbidly obese females seeking bariatric \\
\hline
\end{tabular}

This article is protected by copyright. All rights reserved. 


\begin{tabular}{|c|c|c|c|c|c|c|c|c|}
\hline & & & & & & & & surgery. \\
\hline Leshem, 2018 & 43 & LSG, OAGB & $41.6 \pm 11.8$ & 100 & $41.6 \pm 4.6$ & $27.5 \pm 4.4$ & 17 & $\begin{array}{l}\text { Female patients (age } \geq 18 \text { years) with BMI } \\
\text { between } 35-39.9 \mathrm{~kg} / \mathrm{m}^{2} \text { associated with } \\
\text { comorbidities, BMI }>40 \mathrm{~kg} / \mathrm{m}^{2} \text {, or BMI of } 30- \\
35 \mathrm{~kg} / \mathrm{m}^{2} \text { who previously failed bariatric } \\
\text { surgery, and able to read Hebrew. }\end{array}$ \\
\hline Maher, 2008 & 324 & LRYGB & $42.4 \pm 11.0$ & 80.5 & $49.5 \pm 9.0$ & - & 29.9 & $\begin{array}{l}\text { All patients undergoing L-GBP were within the } \\
\text { guidelines of the } 1991 \text { National Institutes of } \\
\text { Health Con-sensus Conference }\end{array}$ \\
\hline O'Boyle, 2015 & 82 & $\begin{array}{l}\text { LRYGB, LSG, } \\
\text { LAGB }\end{array}$ & $49 \pm 9.7$ & 100 & $50 \pm 6.3$ & $34 \pm 6.8$ & - & $\begin{array}{l}\text { Bariatric surgery was performed in all cases in } \\
\text { accordance with international guidelines (NICE, } \\
\text { NIH, IFSO }\end{array}$ \\
\hline Olivera, 2012 & 36 & RYGB, LAGB, LSG & $31.28 \pm 12.28$ & 100 & $45.76 \pm 6.48$ & 31.55 & - & $\begin{array}{l}\text { Females scheduled to undergo bariatric surgery } \\
\text { for weight loss who were at least } 45 \mathrm{~kg} \text { above } \\
\text { ideal body weight (using Metropolitan Life- } \\
\text { Insurance Tables), and/or body mass index } \\
(\mathrm{BMI})>35 \mathrm{~kg} / \mathrm{m}^{2} \text { with comorbidities, or BMI }> \\
40 \mathrm{~kg} / \mathrm{m}^{2} \text { without co- morbidities. }\end{array}$ \\
\hline \multirow[t]{2}{*}{ Palleschi, 2015} & 120 & LSG & $\begin{array}{l}\text { Female: } 64.4 \pm \\
7.77 ; \text { Male: } \\
42.4 \pm 8.24\end{array}$ & 50 & $\begin{array}{l}\text { Female: } 41.2 \pm \\
2.8 ; \text { Male: } \\
40.7 \pm 4.9\end{array}$ & $\begin{array}{l}\text { Female: } 32 \pm \\
1.8 ; \text { Male: } 31 \\
\pm 0.9\end{array}$ & 70 & $\begin{array}{l}\text { Inclusion criteria were morbid obesity (BMI }>40 \\
\mathrm{~kg} / \mathrm{m}^{2} \text { ), age } 18 \text { and } 60 \mathrm{y} \text {, and eligibility for } \\
\text { laparoscopic surgery. }\end{array}$ \\
\hline & 120 & Control group & $\begin{array}{l}\text { Female: } 63.6 \pm \\
\text { 3.3; Male: } 44 \\
\pm 6.34\end{array}$ & 50 & $\begin{array}{l}\text { Female: } 40 \pm \\
2.7 ; \text { Male: } 41 \\
\pm 5.5\end{array}$ & $\begin{array}{l}\text { Female: } 40.2 \pm \\
3.6 ; \text { Male: } 41.7 \\
\pm 4.5\end{array}$ & 71 & $\begin{array}{l}\left.\text { Class } 2 \text { obesity (BMI } 35-39.9 \mathrm{~kg} / \mathrm{m}^{2}\right) \text { associated } \\
\text { with comorbidities, class } 3 \text { obesity (BMI }>40 \\
\mathrm{~kg} / \mathrm{m}^{2} \text { ) and obese women with BMI } 30-35 \\
\mathrm{~kg} / \mathrm{m}^{2} \text { who had previously failed bariatric } \\
\text { surgery. Other criteria for inclusion were age } \\
\text { over } 18 \text { years }\end{array}$ \\
\hline Ranasinghe, 2010 & 196 & LAGB & $\begin{array}{l}\text { Male: } 52.8 \\
\text { Female: } 47.8\end{array}$ & 81.63 & $\begin{array}{l}\text { Male: } 47.3 \pm \\
12.67 ; \text { Female: } \\
43.5 \pm 6.65\end{array}$ & $\begin{array}{l}\text { Male: } 38.4 \pm \\
6.18 ; \text { Female: } \\
35.5 \pm 6.80\end{array}$ & - & $\begin{array}{l}\text { Males and females who had underwent LGB } \\
\text { over a period of } 10 \text { years }\end{array}$ \\
\hline Roberson, 2010 & 193 & LAGB, RYGB & - & 83 & $50.2 \pm 7.7$ & $32.9 \pm 7.5$ & 15 & $\begin{array}{l}\text { Adults who underwent bariatric surgery at } \\
\text { University of Wisconsin Hospital and Clinics, } \\
\text { Madison, Wisconsin from July } 2002 \text { to May } \\
2006\end{array}$ \\
\hline
\end{tabular}

This article is protected by copyright. All rights reserved. 


\section{Said, 2016}

116

LSG, LRYGB

$47.6 \pm 11.9$

72

$43.6 \pm 6.9$

$31.6 \pm 5.2$

Control group

LRGYB
Scozzari, 2013
71

Control group

$41.3 \pm 14$

$44 \pm 9$

73

$50 \pm 7$

$25 \pm 7$

Female: 45.5;

range: $41.6-$

50.9; Male:

47.1 ; range:

42.6-52.8

\begin{tabular}{llllllll}
\hline Uruc, 2016 & 22 & LSG & $34.59 \pm 8.07$ & 0 & $49.57 \pm 6.21$ & $38.98 \pm 5.51$ & 0 \\
\hline Vella, 2009 & 126 & Not specified & $45.4 \pm 10.49$ & 100 & $47.5 \pm 8.12$ & $31 \pm 6.47$ & -
\end{tabular}

Screening Questionnaire

Each patient was discussed during a

multidisciplinary meeting to choose the

technique best adapted (LSG or bypass) to the patient's characteristics

40 obese patients followed in the nutrition department with no surgery scheduled

Morbidly obese female patients with obesity-

related comorbidities; RGYB patients included in the study with no further inclusion or exclusion criteria according to the purpose of the study

Inclusion criteria were female gender, standard criteria for bariatric surgery, absence of previous surgical, obstetrical, or traumatic anal sphincterial injuries, absence of previous anorectal surgery, absence of chronic diarrhea, inflammatory bowel diseases, and neurological diseases involving pelvic innervation, and informed consent to the study protocol. As control group, 71 age-matched healthy volunteer non-obese women selected with the same inclusion criteria, except for obesity Patients greater than 18 years of age were selected as per European consensus guidelines on surgery for severe obesity (BMI $>40 \mathrm{~kg} / \mathrm{m}^{2}$ or $>35 \mathrm{~kg} / \mathrm{m}^{2}$ with comorbidities).

Patients 18 years or older seeking first time bariatric surgical procedure with a participating surgeon were recruited. Participants had to complete the UIQ at baseline and 1 or more follow-up assessments within the first 3 postoperative years

Patients who do not satisfy the exclusion criteria as stated

All women who underwent bariatric surgery at Temple University Hospital between January

This article is protected by copyright. All rights reserved. 
2004 and March 2006 were identified from the Preoperative Information Systems database.

\begin{tabular}{|c|c|c|c|c|c|c|c|c|}
\hline Wasserberg, 2009 & 46 & RYGB, DS, SG & $\begin{array}{l}45 \text {; range: } 20- \\
67\end{array}$ & 100 & $\begin{array}{l}45 \text {; range: } 35- \\
75\end{array}$ & $\begin{array}{l}28 \text {; range: } 22- \\
44\end{array}$ & 26 & $\begin{array}{l}\text { Women with BMI of }>=35 \mathrm{~kg} / \mathrm{m}^{2} \text { attending the } \\
\text { University of Southern California Bariatric } \\
\text { Surgery Program from December } 2003 \text { to } \\
\text { December } 2005 \text {. Patients who underwent } \\
\text { surgery during the study period and achieved a } \\
>50 \% \text { excess weight loss postoperatively }\end{array}$ \\
\hline Whitcomb, 2012 & 69 & LAGB, SG & $43.3 \pm 11.8$ & 100 & $39.7 \pm 6.2$ & $34.4 \pm 5.8$ & - & $\begin{array}{l}\text { Women with a BMI }>=30 \mathrm{~kg} / \mathrm{m}^{2} \text { meeting surgical } \\
\text { eligibility were screened by telephone or in- } \\
\text { person interview, with eligibility criteria } \\
\text { including severe or morbid obesity } \\
\left(\text { BMI }>=40 \mathrm{~kg} / \mathrm{m}^{2} \text { ) or obesity (BMI }>=30 \mathrm{~kg} / \mathrm{m}^{2} \text { ) }\right. \\
\text { in the presence of two US NIH-identified } \\
\text { comorbidities }\end{array}$ \\
\hline
\end{tabular}

Table 1. Characteristics of eligible studies (Pre-op, preoperative; Post-op, post-operative; BMI, Body mass index; LAGB, Laparoscopic adjustable gastric binding; LSG, Laparoscopic sleeve gastrectomy; RYGB, Roux-en-y gastric bypass; LRYGB, Laparoscopic roux-en-y gastric bypass; SG, Sleeve gastrectomy; JIB, jejunoileal bypass; OAGB, one-anastomosis gastric bypass; -, Not available)

This article is protected by copyright. All rights reserved. 


\begin{tabular}{|c|c|c|c|c|c|c|}
\hline Study & $\begin{array}{l}\text { Validated } \\
\text { questionnaire used }\end{array}$ & Type of survey & Type of UI assessed & Specific SUI question used & Specific UUI question used & $\begin{array}{l}\text { Response options/ Definition of } \\
\text { normal-abnormal }^{\text {a }}\end{array}$ \\
\hline Ahroni, 2005 & $\begin{array}{l}\text { Not validated, author- } \\
\text { created }\end{array}$ & In person & Stress & - & - & $\begin{array}{l}\text { Much better/Somewhat better/No } \\
\text { change/Somewhat worse/Much } \\
\text { worse/Don't know }\end{array}$ \\
\hline Bulbuller, 2017 & ICIQ-UI-SF, IIQ-7 & $\begin{array}{l}\text { Given } \\
\text { questionnaire }\end{array}$ & Stress and urgency & When does urine leak? & When does urine leak? & $\begin{array}{l}\text { Never/Leaks before you can get to } \\
\text { the toilet (UUI)/Leaks when you } \\
\text { cough or sneeze (SUI)/Leaks when } \\
\text { you are active or exercising } \\
\text { (SUI)/All the above (MUI) }\end{array}$ \\
\hline Bump, 1992 & $\begin{array}{l}\text { Not validated, author- } \\
\text { created }\end{array}$ & In person & Stress and urgency & - & - & $\begin{array}{l}\text { No complaints/Complaints of SUI } \\
\text { (SUI)/Complaints of UUI (UUI)/ } \\
\text { Complaints of both SUI and UUI } \\
\text { (MUI) }\end{array}$ \\
\hline Burgio, 2007 & $\begin{array}{l}\text { UDI-6-SF, IIQ-7, } \\
\text { MESA }\end{array}$ & $\begin{array}{l}\text { Given } \\
\text { questionnaire }\end{array}$ & Stress and urgency & $\begin{array}{l}\text { Does coughing gently or } \\
\text { hard, sneezing, lifting things, } \\
\text { bending over, vomiting, } \\
\text { straining to do something, } \\
\text { laughing, sexual activity, } \\
\text { walking briskly, or jogging } \\
\text { ever cause you to lose urine? }\end{array}$ & $\begin{array}{l}\text { Does finding the toilet is } \\
\text { occupied or being delayed in } \\
\text { getting to use it, having the } \\
\text { feeling that your bladder is } \\
\text { very full, or having an urge to } \\
\text { urinate ever cause the loss of } \\
\text { urine beyond your control? }\end{array}$ & Never/Rarely/Sometimes/Often \\
\hline Castro, 2012 & $\begin{array}{l}\text { King's Health } \\
\text { Questionnaire- } \\
\text { Portuguese }\end{array}$ & $\begin{array}{l}\text { In person, given } \\
\text { questionnaire }\end{array}$ & $\begin{array}{l}\text { Any urinary } \\
\text { incontinence }\end{array}$ & - & - & No/Yes \\
\hline Choi, 2010 & $\begin{array}{l}\text { Not validated, author- } \\
\text { created }\end{array}$ & $\begin{array}{l}\text { In person, given } \\
\text { questionnaire }\end{array}$ & Stress & - & - & - \\
\hline Cuicchi, 2013 & $\begin{array}{l}\text { PFDI-20, UDI-6-SF, } \\
\text { PFIQ-7, IIQ-7 }\end{array}$ & $\begin{array}{l}\text { Given } \\
\text { Questionnaire }\end{array}$ & Stress and urgency & $\begin{array}{l}\text { Do you experience, and if so, } \\
\text { how much are you bothered } \\
\text { by leakage related to physical } \\
\text { activity, coughing, or } \\
\text { sneezing? }\end{array}$ & $\begin{array}{l}\text { Do you experience, and if so, } \\
\text { how much are you bothered } \\
\text { by leakage related to feeling } \\
\text { of urgency? }\end{array}$ & $\begin{array}{l}\text { Not at all/A little } \\
\text { bit/Moderately/Greatly }\end{array}$ \\
\hline Daucher, 2010 & $\begin{array}{l}\text { PFDI, UDI, PFIQ, UIQ, } \\
\text { PISQ-12 }\end{array}$ & $\begin{array}{l}\text { Given } \\
\text { Questionnaire, 3- } \\
\text { day voiding } \\
\text { diaries }\end{array}$ & Stress and urgency & $\begin{array}{l}\text { Do you experience, and if so, } \\
\text { how much are you bothered } \\
\text { by leakage related to physical } \\
\text { activity, coughing, or } \\
\text { sneezing? }\end{array}$ & $\begin{array}{l}\text { Do you experience, and if } \\
\text { so, how much are you } \\
\text { bothered by leakage } \\
\text { related to feeling of } \\
\text { urgency? }\end{array}$ & $\begin{array}{l}\text { Not at all/A little } \\
\text { bit/Moderately/Greatly }\end{array}$ \\
\hline Deitel, 1988 & $\begin{array}{l}\text { Not validated, author- } \\
\text { created }\end{array}$ & In person & Stress & - & - & - \\
\hline
\end{tabular}

This article is protected by copyright. All rights reserved. 


\begin{tabular}{|c|c|c|c|c|c|c|}
\hline Gabriel, 2018 & PFDI-20, UDI-6-SF & $\begin{array}{l}\text { Mail or online } \\
\text { questionnaire }\end{array}$ & Stress and urgency & $\begin{array}{l}\text { Do you usually experience } \\
\text { urine leakage related to } \\
\text { coughing, sneezing, or } \\
\text { laughing? }\end{array}$ & $\begin{array}{l}\text { Do you usually experience } \\
\text { urine leakage associated with } \\
\text { a feeling of urgency, that is, a } \\
\text { strong sensation of needing } \\
\text { to go to the bathroom? }\end{array}$ & $\begin{array}{l}\text { Not at all/A little } \\
\text { bit/Moderately/Greatly }\end{array}$ \\
\hline Kim, 2017 & OABSS, PPBC, Sandvik & Given & Any urinary & Do you leak when coughing, & Is leakage accompanied & Not at all/Slight/Moderate/Severe \\
\hline Knepfler, 2016 & PFDI-20, UDI-6 & $\begin{array}{l}\text { Given } \\
\text { questionnaire }\end{array}$ & $\begin{array}{l}\text { Any urinary } \\
\text { incontinence }\end{array}$ & $\begin{array}{l}\text { Do you experience, and if so, } \\
\text { how much are you bothered } \\
\text { by leakage related to physical } \\
\text { activity, coughing, or } \\
\text { sneezing? }\end{array}$ & $\begin{array}{l}\text { Do you experience, and if so, } \\
\text { how much are you bothered } \\
\text { by leakage related to feeling } \\
\text { of urgency? }\end{array}$ & $\begin{array}{l}\text { Not at all/A little } \\
\text { bit/Moderately/Greatly }\end{array}$ \\
\hline Knoepp, 2013 & - & $\begin{array}{l}\text { Insurance } \\
\text { database }\end{array}$ & $\begin{array}{l}\text { Any urinary } \\
\text { incontinence }\end{array}$ & - & - & $\begin{array}{l}\text { None/CPT code for previous UI } \\
\text { procedures/ICD-9 code for } \\
\text { UI/Prescription of UI medication. }\end{array}$ \\
\hline Kuruba, 2007 & $\begin{array}{l}\text { MESA, Sandvik } \\
\text { questionnaire }\end{array}$ & $\begin{array}{l}\text { Telephone } \\
\text { interview, given } \\
\text { questionnaire }\end{array}$ & Stress and urgency & $\begin{array}{l}\text { Does coughing gently or } \\
\text { hard, sneezing, lifting things, } \\
\text { bending over, vomiting, } \\
\text { straining to do something, } \\
\text { laughing, sexual activity, } \\
\text { walking briskly, or jogging } \\
\text { ever cause you to lose urine? }\end{array}$ & $\begin{array}{l}\text { Does finding the toilet is } \\
\text { occupied or being delayed in } \\
\text { getting to use it, having the } \\
\text { feeling that your bladder is } \\
\text { very full, or having an urge to } \\
\text { urinate ever cause the loss of } \\
\text { urine beyond your control? }\end{array}$ & Never/Rarely/Sometimes/Often \\
\hline Laungani, 2009 & ICIQ-UI-SF & $\begin{array}{l}\text { Given } \\
\text { questionnaire }\end{array}$ & Stress and urgency & When does urine leak? & When does urine leak? & $\begin{array}{l}\text { Never/Leaks before you can get to } \\
\text { the toilet (UUI)/Leaks when you } \\
\text { cough or sneeze (SUI)/Leaks when } \\
\text { you are active or exercising } \\
\text { (SUI)/All the above (MUI) }\end{array}$ \\
\hline Leshem, 2018 & $\begin{array}{l}\text { ICIQ-UI-SF, BFLUTS- } \\
\text { SF, PFDI-20, UDI-6, } \\
\text { PISQ-12 }\end{array}$ & $\begin{array}{l}\text { Given } \\
\text { questionnaire }\end{array}$ & Stress and urgency & When does urine leak? & When does urine leak? & $\begin{array}{l}\text { Never/Leaks before you can get to } \\
\text { the toilet (UUI)/Leaks when you } \\
\text { cough or sneeze (SUI)/Leaks when } \\
\text { you are active or exercising } \\
\text { (SUI)/All the above (MUI) }\end{array}$ \\
\hline Maher, 2008 & $\begin{array}{l}\text { Not validated, author- } \\
\text { created }\end{array}$ & In person & $\begin{array}{l}\text { Any urinary } \\
\text { incontinence }\end{array}$ & - & - & - \\
\hline McDermott, 2012 & PFDI-20, PFIQ-7 & $\begin{array}{l}\text { In person, given } \\
\text { questionnaire }\end{array}$ & Stress and urgency & $\begin{array}{l}\text { Do you usually experience } \\
\text { urine leakage related to } \\
\text { coughing, sneezing or } \\
\text { laughing? }\end{array}$ & $\begin{array}{l}\text { Do you usually experience } \\
\text { urine leakage associated with } \\
\text { a feeling of urgency, that is, a } \\
\text { strong sensation of needing } \\
\text { to go to the bathroom? }\end{array}$ & $\begin{array}{l}\text { Not present/not at } \\
\text { all/somewhat/moderately/quite a bit }\end{array}$ \\
\hline
\end{tabular}

This article is protected by copyright. All rights reserved. 


\begin{tabular}{|c|c|c|c|c|c|c|}
\hline O'Boyle, 2015 & ICIQ-UI-SF & $\begin{array}{l}\text { In person, given } \\
\text { questionnaire }\end{array}$ & Stress and urgency & When does urine leak? & When does urine leak? & $\begin{array}{l}\text { Never/Leaks before you can get to } \\
\text { the toilet (UUI)/Leaks when you } \\
\text { cough or sneeze (SUI)/Leaks when } \\
\text { you are active or exercising } \\
\text { (SUI)/All the above (MUI) }\end{array}$ \\
\hline Olivera, 2012 & PFIQ/IIQ, PISQ-12 & $\begin{array}{l}\text { In person, mail, } \\
\text { telephone } \\
\text { interview }\end{array}$ & $\begin{array}{l}\text { Any urinary } \\
\text { incontinence }\end{array}$ & - & - & Yes/No \\
\hline Palleschi, 2015 & $\mathrm{OABq}-\mathrm{SF}$ & $\begin{array}{l}\text { In person, given } \\
\text { questionnaire }\end{array}$ & Urgency & $\begin{array}{l}\text { N/A; SUI part of exclusion } \\
\text { criteria }\end{array}$ & $\begin{array}{l}\text { During the past } 4 \text { weeks, how } \\
\text { bothered were you by an } \\
\text { uncomfortable urge to } \\
\text { urinate? During the past } 4 \\
\text { weeks, how bothered were } \\
\text { you by a sudden urge to } \\
\text { urinate with little or no } \\
\text { warning? }\end{array}$ & $\begin{array}{l}\text { Not at all, a little bit, somewhat, quit } \\
\text { a bit, a great deal, a very great deal }\end{array}$ \\
\hline Ranasinghe, 2010 & ICIQ-SF & Mailed & Stress and urgency & When does urine leak? & When does urine leak? & $\begin{array}{l}\text { Never/Leaks before you can get to } \\
\text { the toilet (UUI)/Leaks when you } \\
\text { cough or sneeze (SUI)/Leaks when } \\
\text { you are active or exercising } \\
\text { (SUI)/All the above (MUI) }\end{array}$ \\
\hline Roberson, 2010 & $\begin{array}{l}\text { Not validated; author- } \\
\text { created }\end{array}$ & Mailed & Stress, urgency, mixed & $\begin{array}{l}\text { Do you leak urine when you } \\
\text { perform some physical } \\
\text { activity such as coughing, } \\
\text { sneezing, lifting, or exercise? }\end{array}$ & $\begin{array}{l}\text { Do you leak urine when you } \\
\text { have the strong feeling that } \\
\text { you needed to empty your } \\
\text { bladder but cannot get to the } \\
\text { toilet fast enough? }\end{array}$ & Yes/No \\
\hline Romero-Talamas, 2015 & $\begin{array}{l}\text { PFDI-20, PFIQ-7, PISQ- } \\
12\end{array}$ & $\begin{array}{l}\text { In person, given } \\
\text { questionnaire }\end{array}$ & Stress and urgency & $\begin{array}{l}\text { Do you usually experience } \\
\text { urine leakage related to } \\
\text { coughing, sneezing or } \\
\text { laughing? }\end{array}$ & $\begin{array}{l}\text { Do you usually experience } \\
\text { urine leakage associated with } \\
\text { a feeling of urgency, that is, a } \\
\text { strong sensation of needing } \\
\text { to go to the bathroom? }\end{array}$ & $\begin{array}{l}\text { Not present/not at } \\
\text { all/somewhat/moderately/quite a bit }\end{array}$ \\
\hline Said, 2016 & ICIQ & $\begin{array}{l}\text { In person, given } \\
\text { questionnaire, } \\
\text { follow up by mail }\end{array}$ & Stress and urgency & When does urine leak? & When does urine leak? & $\begin{array}{l}\text { Never/Leaks before you can get to } \\
\text { the toilet (UUI)/Leaks when you } \\
\text { cough or sneeze (SUI)/Leaks when } \\
\text { you are active or exercising } \\
\text { (SUI)/All the above (MUI) }\end{array}$ \\
\hline Schouten, 2013 & $\begin{array}{l}\text { Not validated; author } \\
\text { created }\end{array}$ & $\begin{array}{l}\text { In person, given } \\
\text { questionnaire }\end{array}$ & $\begin{array}{l}\text { Any urinary } \\
\text { incontinence }\end{array}$ & - & - & Yes/No \\
\hline Scozzari, 2013 & PFDI-20, PFIQ-7 & In person, given & Stress and urgency & Do you usually experience & Do you usually experience & Not present/not at \\
\hline
\end{tabular}

This article is protected by copyright. All rights reserved. 


\begin{tabular}{|c|c|c|c|c|c|c|}
\hline & & questionnaire & & $\begin{array}{l}\text { urine leakage related to } \\
\text { coughing, sneezing or } \\
\text { laughing? }\end{array}$ & $\begin{array}{l}\text { urine leakage associated with } \\
\text { a feeling of urgency, that is, a } \\
\text { strong sensation of needing } \\
\text { to go to the bathroom? }\end{array}$ & all/somewhat/moderately/quite a bit \\
\hline Srinivasa, 2010 & $\begin{array}{l}\text { Not validated; author } \\
\text { created }\end{array}$ & Retrospective & Stress & - & - & - \\
\hline Subak, 2015 & UIQ & $\begin{array}{l}\text { In person, given } \\
\text { questionnaire }\end{array}$ & Stress & $\begin{array}{l}\text { In the past } 3 \text { months, how } \\
\text { often have you typically } \\
\text { leaked urine, even a small } \\
\text { amount with a physical } \\
\text { activity like coughing, } \\
\text { sneezing, lifting, or exercise? }\end{array}$ & $\begin{array}{l}\text { In the past } 3 \text { months, how } \\
\text { often have you typically felt } \\
\text { an urge or the feeling that } \\
\text { you needed to empty your } \\
\text { bladder, but you could not } \\
\text { get to the toilet fast enough? }\end{array}$ & $\begin{array}{l}\text { Never/ less than once per month, } \\
\text { monthly (once or more each month), } \\
\text { weekly (once or more each week), or } \\
\text { daily (once or more each day). }\end{array}$ \\
\hline Uruc, 2016 & ICIQ-SF & $\begin{array}{l}\text { Given } \\
\text { questionnaire }\end{array}$ & Stress and urgency & When does urine leak? & When does urine leak? & $\begin{array}{l}\text { Never/Leaks before you can get to } \\
\text { the toilet (UUI)/Leaks when you } \\
\text { cough or sneeze (SUI)/Leaks when } \\
\text { you are active or exercising } \\
\text { (SUI)/All the above (MUI) }\end{array}$ \\
\hline Vella, 2009 & UDI-6, IIQ-7 & Mailed & Stress and urgency & $\begin{array}{l}\text { Urine leakage related to } \\
\text { physical activity, coughing, } \\
\text { or sneezing? }\end{array}$ & $\begin{array}{l}\text { Urine leakage related to } \\
\text { physical activity, coughing or } \\
\text { sneezing? }\end{array}$ & $\begin{array}{l}\text { Not at all/A little } \\
\text { bit/Moderately/Greatly }\end{array}$ \\
\hline Wasserberg, 2009 & PFIQ, PFDI & Given, in person & Stress and urgency & $\begin{array}{l}\text { Do you usually experience } \\
\text { urine leakage related to } \\
\text { coughing, sneezing or } \\
\text { laughing? }\end{array}$ & $\begin{array}{l}\text { Do you usually experience } \\
\text { urine leakage associated with } \\
\text { a feeling of urgency, that is, a } \\
\text { strong sensation of needing } \\
\text { to go to the bathroom? }\end{array}$ & $\begin{array}{l}\text { Not present/not at } \\
\text { all/somewhat/moderately/quite a bit }\end{array}$ \\
\hline Whitcomb, 2012 & PFIQ, PFDI, PISQ & Given & Stress and urgency & $\begin{array}{l}\text { Do you usually experience } \\
\text { urine leakage related to } \\
\text { coughing, sneezing or } \\
\text { laughing? }\end{array}$ & $\begin{array}{l}\text { Do you usually experience } \\
\text { urine leakage associated with } \\
\text { a feeling of urgency, that is, a } \\
\text { strong sensation of needing } \\
\text { to go to the bathroom? }\end{array}$ & $\begin{array}{l}\text { Not present/not at } \\
\text { all/somewhat/moderately/quite a bit }\end{array}$ \\
\hline
\end{tabular}

Table 2. Urinary incontinence assessment in eligible studies (UI, urinary incontinence; ICIQ-UI-SF, International consultation on incontinence questionnaire - urinary incontinence - short form; IIQ, Incontinence impact questionnaire; UDI-6-SF, Urogenital distress inventory-6-short form; MESA, Medical, Epidemiologic and Social Aspects of Aging Questionnaire; PFDI-20, Pelvic Floor Disability Index-20; PFIQ-7, Pelvic floor impact questionnaire 7; PISQ-12, Pelvic organic prolapse/urinary incontinence sexual questionnaire 12; OABSS, Overactive bladder symptom score; PPBC, Patient perception of bladder condition; BFLUTS, Bristol Female Lower Urinary Tract Symptoms; UIQ, Urinary Impact Questionnaire; OAB-q, Overactive Bladder Questionnaire; -, not reported)

${ }^{a}$ Cut-off point (threshold) used for normal versus abnormal symptom occurrence. Response options classified as abnormal are shown in boldface type. All studies used the same response options for both SUI and UUI.

This article is protected by copyright. All rights reserved. 


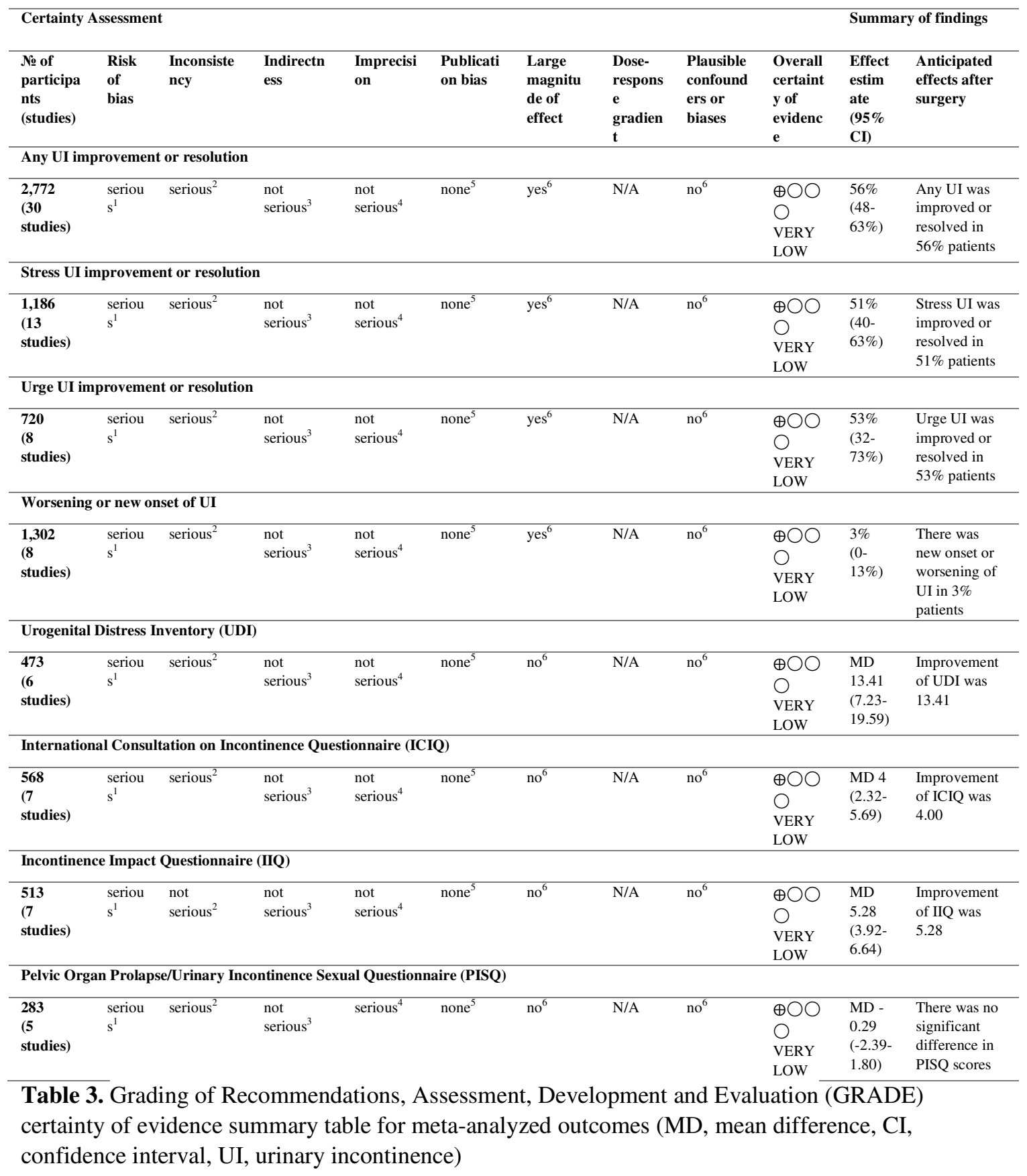

This article is protected by copyright. All rights reserved. 


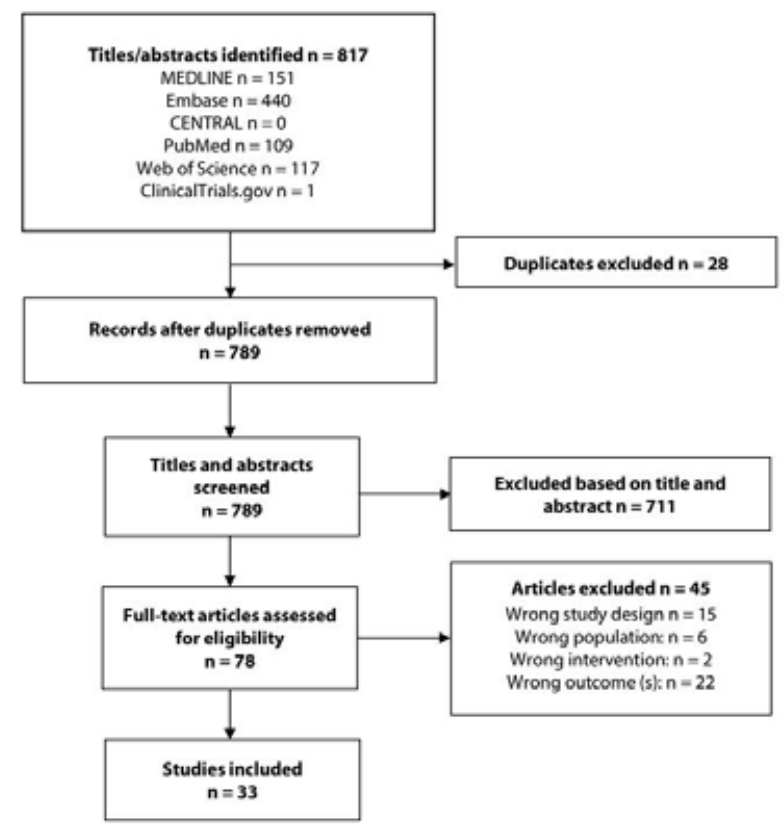

This article is protected by copyright. All rights reserved. 

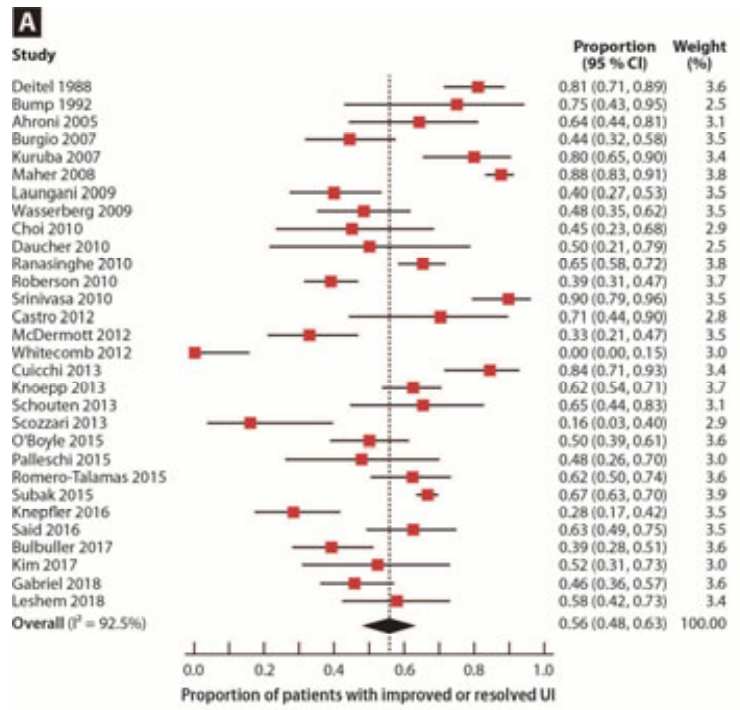

B

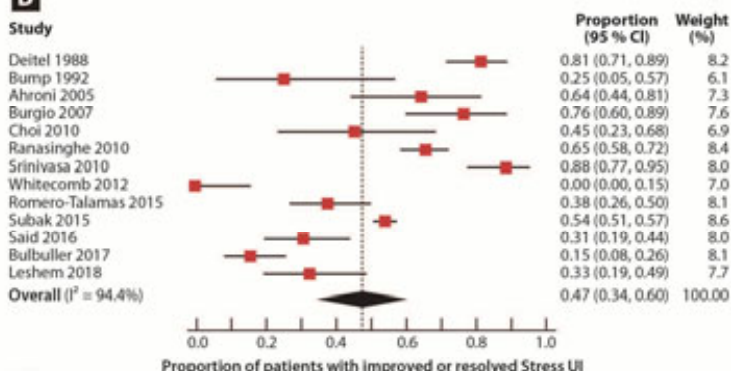

C

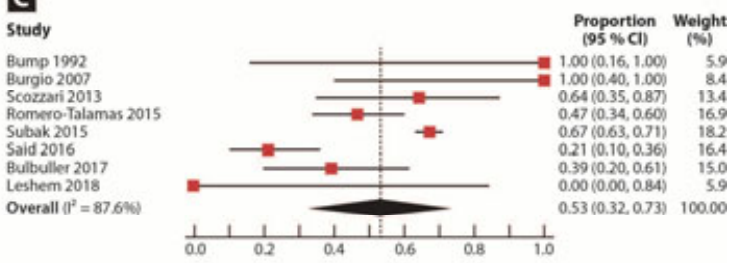

D

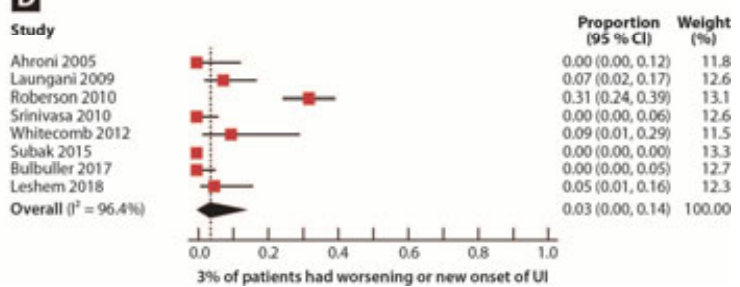

This article is protected by copyright. All rights reserved. 
A

Studies

Burgio 2007

Vella 2009

Daucher 2010

McDermott 2012

Cuicchi 2013

Knepfler 2016

Total $(95 \% \mathrm{Cl})$

Heterogeneity: $\operatorname{Tau}^{2}=42.69 ; \mathrm{Ch}^{2}=30.20, \mathrm{~d} f=$

Test for overall effect: $Z=4.25$ ( $P<0.0001)$

\section{B}

\begin{tabular}{|c|c|c|c|c|c|c|c|c|}
\hline \multirow[b]{2}{*}{ Studies } & \multicolumn{3}{|c|}{ Before bariatric surgery } & \multicolumn{3}{|c|}{ After bariatric surgery } & \multirow{2}{*}{$\begin{array}{l}\text { Weight } \\
(\%)\end{array}$} & \multirow{2}{*}{$\begin{array}{l}\text { Mean difference } \\
\text { IV, random, } 95 \% \mathrm{CI}\end{array}$} \\
\hline & Mean & SD & Total & Mean & SD & Total & & \\
\hline 2009 & 7.60 & 4.00 & 5 & 1.80 & 3.00 & 25 & 14.0 & 5.8 \\
\hline singhe 2010 & 4.58 & 4.74 & 176 & 3.49 & 4.59 & 17 & & 6) \\
\hline yle 2015 & 9.30 & 4.40 & 8 & 4.90 & 5.20 & 8 & & 7) \\
\hline 016 & 1.82 & 2.15 & 2 & 0.32 & 0.95 & 22 & 1 & $2.48)$ \\
\hline 6 & 3.90 & 5.30 & 115 & 1.00 & 3.00 & 11 & 14.9 & $2.90(1.79,4.01)$ \\
\hline uller 2017 & 9.55 & 5.52 & 72 & 3.09 & 2.97 & 72 & 14.2 & $6.46(5.01,7.91)$ \\
\hline hem 2018 & 9.49 & 4.00 & 43 & 2.91 & 3.90 & & 12.6 & $6.58(4.42,8.74)$ \\
\hline $\mathrm{l}(95 \% \mathrm{Cl})$ & & & 568 & & & 510 & 100.0 & $4.00(2.32,6.58)$ \\
\hline
\end{tabular}

Heterogeneity: $\operatorname{Tau}^{2}=4.66 ; \mathrm{Chi}^{2}=71.73, \mathrm{df}=6(\mathrm{P}<0.00001) ; \mathrm{I}^{2}=92 \%$

Test for overall effect: $Z=4.65$ ( $P<0.00001)$

C

Studies

Before bariatric surgery After bariatric surgery Mean SD Total Mean SD Total

Burgio 2007

Vella 2009

Daucher 2010

Olivera 2012

McDermott 2012

Cuicchi 2013

Bulbuller 2017

Total $(95 \% \mathrm{Cl})$

$\begin{array}{lll}15.80 & 24.50 \quad 94\end{array}$

$\begin{array}{rrr}52.00 & 0 & 126\end{array}$

$\begin{array}{lll}11.00 & 15.00 & 34\end{array}$

$\begin{array}{lll}35.85 & 13.89 & 36\end{array}$

$24.00 \quad 21.50 \quad 64$

$\begin{array}{llll}5.50 & 14.20 \quad 87\end{array}$

$\begin{array}{lll}7.23 & 3.62 & 72\end{array}$

$\begin{array}{llll}6.10 & 18.00 & 94\end{array}$

$\begin{array}{lll}35.00 & 0 & 126\end{array}$

$\begin{array}{llll}6.75 & 10.00 \quad 34\end{array}$

$\begin{array}{rrr}27.12 & 4.53 & 36 \\ 17.75 & 17.75 & 63\end{array}$

$\begin{array}{lll}17.75 & 17.75 & 63\end{array}$

$\begin{array}{lll}0.54 & 0.50 & 87\end{array}$

$\mathrm{df}=5(P=0.32) ; I^{2}=14 \%$

Heterogeneity: $\operatorname{Tau}^{2}=0.52 ; \mathrm{Chi}^{2}=5.81, \mathrm{df}=5$

Test for overall effect: $Z=7.59(P<0.00001)$

D

Studies

Before bariatric surgery A

Daucher 2010

Olivera 2012

Whitcomb 2012

Romero-Talamas $2015 \quad 34.20 \quad 5.10 \quad 72$

Leshem 2018

$$
\text { Mean SD Total }
$$

After bariatric surgery

Mean SD Total

$\begin{array}{lll}25.00 & 5.00 \quad 34\end{array}$

$38.22 \quad 6.03 \quad 36$

$\begin{array}{lll}14.40 & 5.40 & 69\end{array}$

$\begin{array}{lll}36.00 & 6.00 & 72\end{array}$

$\begin{array}{lll}38.10 & 5.00 \quad 18\end{array}$

18
229

Heterogeneity: Tau $^{2}=4.15 ;$ Chi $^{2}=15.30$, df $=4(P=0.004) ; P^{2}=74 \%$

Test for overall effect: $Z=0.28(P=0.78)$

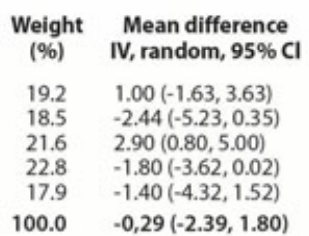

100.0

$0,29(-2.39,1.80)$
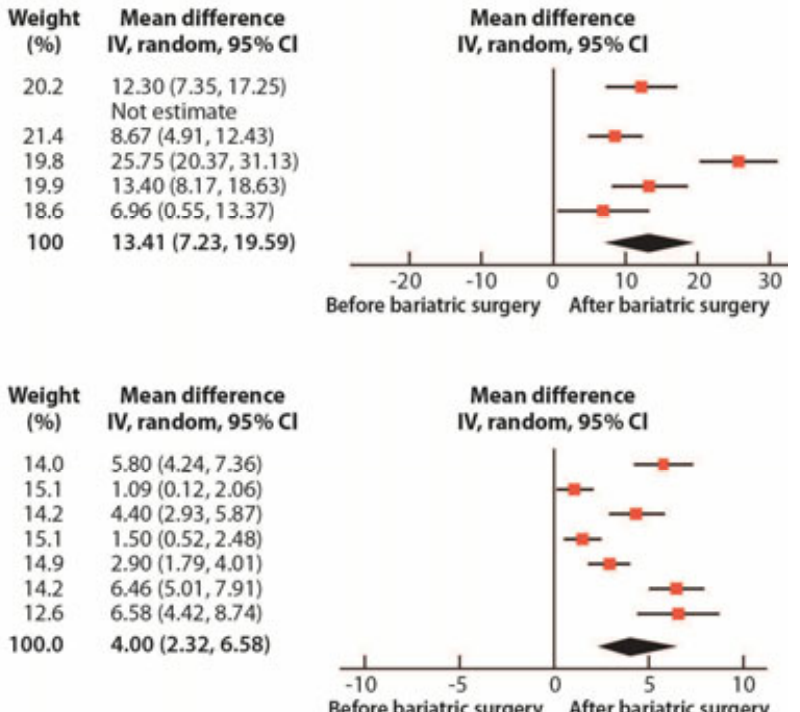

Weight Mean difference

(\%) IV, random, $95 \% \mathrm{Cl}$

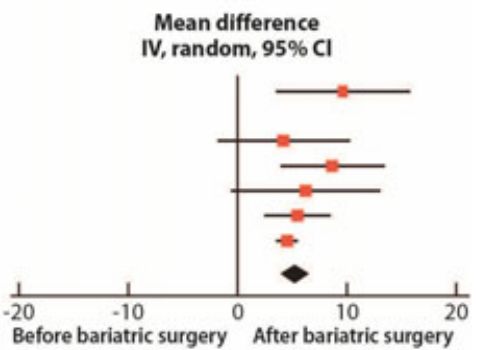

$9.70(3.55,15.85)$

Not estimable

$4.25(-1.81,10.31)$

$8.73(3.96,13.50)$

$6.25(-0.60,13.10)$

$5.50(2.51,8.49)$

$4.49(3.50,5.48)$

$5.28(3.92,6.64)$

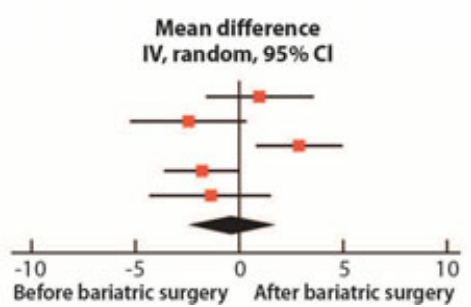

This article is protected by copyright. All rights reserved. 